\title{
COMMENTS
}

\section{Federal Prosecution for Local Vote Fraud Under Section 241 of the Federal Criminal Code}

Section 241 of the federal criminal code ${ }^{1}$ makes it a felony for two or more persons to "conspire to injure, oppress, threaten, or intimidate any citizen in the free exercise or enjoyment of any right or privilege secured to him by the Constitution or laws of the United States . . . ." Since the number of rights "secured by the Constitution" has increased sharply in recent years, the potential reach of section 241 has also expanded dramatically. This automatic expansion of federal criminal law need not be objectionable, but when criminal penalties are imposed for violations of rights which had never before been recognized, fundamental precepts of due process may be violated. Further, since the expansion of constitutional law has been judicial and not legislative, the automatic expansion of section 241 risks the application of federal criminal penalties to areas where Congress had no wish to apply them. Most of the difficulties faced by the courts in applying the criminal civil rights statutes $^{3}$ have stemmed from these two problems.

I 18 U.S.C. $\S 241$ (1970). Maximum punishment for violation of section 241 is a $\$ 10,000$ fine or 10 years imprisonment, or both.

218 U.S.C. $\& 242$ (1970) protects essentially the same rights:

Whoever, under color of any law, statute, ordinance, regulation, or custom, willfully subjects any inhabitant of any State, Territory, or District to the deprivation of any rights, privileges, or immunities secured or protected by the Constitution or laws of the United States, . . . shall be fined not more than $\$ 1,000$ or imprisoned not more than one year, or both ....

3 Although section 242 , unlike section 241 , does not require a conspiracy and, again unlike section 241 , only reaches actions taken under color of state law, the sections are similar in significant respects. Both sections 241 and 242 have been held to contain the same scienter requirement, see United States v. Price, 383 U.S. 787, 806 n.20 (1966); United States v. Guest, 383 U.S. 745, 753-54, 760 (1966); note 68 infra, and to encompass the same rights "secured" by the Constitution. See United States v. Guest, 383 U.S. 745, 753 (1966). Furthermore, because the definition of action "under color of law" in section 242 is the same as that for "state action" under the fourteenth amendment, see United States v. Price, 383 U.S. 787, $794 \mathrm{n} .7$ (1966), and because state action is usually required for violations of fourteenth amendment rights, see note 44 infra, conspiracies to violate fourteenth amendment rights which involve state action can be reached either under section 241 or under section 242 in combination with the general conspiracy statute, 18 U.S.C. $\S 371$ (1970). 
This comment seeks to determine if vote fraud in local elections may currently be punished under section 241 . It long has been recognized that various forms of vote fraud in congressional elections violate rights secured by article I, section 2 and hence are punishable under section $241 .{ }^{4}$ Although similar forms of vote fraud in local elections have been held not to violate constitutional rights or section $241,{ }^{5}$ recent decisions involving the apportionment of state legislatures may have impaired the authority of the earlier decisions. ${ }^{6}$ Local vote fraud may violate rights secured by the Constitution and thus at least arguably may be punished under section $241 .^{7}$

The comment first considers the changes in constitutional law that suggest that local vote fraud violates constitutional rights. It then traces the development and application of the limitations that have been read into section 241 in an attempt to reconcile judicial expansion of constitutional rights with the requirement that penal

Thus, aside from the fact that section 241 protects the rights of "citizens" whereas section 242 protects the rights of "inhabitants," the only operative difference between the sections where fourteenth amendment rights are involved is that section 242 imposes a lighter penalty. For this reason sections 241 and 242 will be treated interchangeably in this comment except where otherwise noted. For a discussion of the independent evolution of these overlapping provisions, see United States v. Williams, 341 U.S. 70, 83 (1951) (Appendix to opinion of Frankfurter, J.).

- See text and notes at notes 11-25 infra.

s See text and note at note 25 infra. Local vote fraud can, in certain circumstances, be reached under federal criminal statutes. When it is possible to prove that illegal votes have been cast in a congressional election in order to conceal the fraud in a local election, sections 241 and 242 can apply. See note 7 infra. Similarly, under 42 U.S.C. $\$ 1973$ i(c) (1970) illegal registration to vote in any election where federal candidates are on the ballot can be punished, even though illegal votes are only cast for state candidates. United States v. Lewin, 467 F.2d 1132 (7th Cir. 1972). In many cases, however, these registration offenses will not be present; of twenty cases of vote fraud arising from the 1972 primary elections in Chicago, no more than half could be prosecuted under $\S 1973 i(c)$. Interview with Theodore T. Scudder, Assistant United States Attorney, in Chicago, Oct. 29, 1975. Moreover, since federal candidates will not be on the ballot in most muncipal elections, neither of these statutes will be useful there. But cf. 42 U.S.C. $\$ 1973 \mathrm{i}(\mathrm{a})$ (1970), discussed in note 153 infra. The courts have split on whether fraud in absentee balloting can be reached under the federal mail fraud statute, 18 U.S.C. $\$ \S 1341-42$ (1970). Compare United States v. States, 488 F.2d 761 (8th Cir. 1973), cert. denied, 417 U.S. 909 (1974), and United States v. Classic, 35 F. Supp. 457 (E.D. La. 1940), with United States v. Randle, 39 F. Supp. 759 (W.D. La. 1941).

- See text and notes at notes 26-53 infra.

7 The Fourth Circuit recently held that ballot box stuffing in a local election is punishable under section 241 because it violates the equal protection clause. Anderson v. United States, 481 F.2d 685 (4th Cir. 1973); see note 53 infra. The Supreme Court, which granted certiorari to consider the correctness of this holding, found it unnecessary to decide the question because the government demonstrated that false votes had also been cast for federal offices. Anderson v. United States, 417 U.S. 211, 219, $227-28$ (1974); see note 78 infra. The Fourth Circuit has since reiterated its view that vote fraud in local elections violates section 241. United States v. Stollings, 501 F.2d 954, 955 (4th Cir. 1974). 
statutes not be unduly vague. Finally, it examines the legislative history of section 241 and the evidence of congressional intent on the subject of federal penalties for local vote fraud, and the judicial use of such information in construing section 241. The comment argues that even though local vote fraud could be held to violate constitutional rights, it should not now be punishable under section 241 because the right to be free from local vote fraud has not yet been established with sufficient certainty to justify criminal prosecutions for its violation. The comment further argues that, even if the right becomes clearly established by future decisions interpreting the Constitution, applying section 241 to local vote fraud would conflict with the congressional intention to avoid federal criminal penalties for purely local vote fraud. Nevertheless, the difficulty in developing a principled use of legislative histories to interpret the scope of section 241 suggests the solution to this problem may be legislative rather than judicial.

\section{The Constitutional Scope of the Right to Vote and to be Free of Vote Fraud}

\section{A. The Traditional Limitation to Congressional Elections}

Section 241 was originally enacted as part of the Enforcement Act of $1870,{ }^{8}$ an act designed to protect the rights of newlyenfranchised black voters by authorizing federal supervision of elections and federal penalties for specified election offenses. ${ }^{9}$ In 1879 , the Supreme Court found that Congress had the power to punish the particular offenses specified in the other sections of the Act when committed in congressional elections under the article I, section 4 power to regulate the "Times, Places and Manner of holding Elections for Senators and Representatives . . . ."10 It was unclear at that time, however, whether section 241 could be used to regulate abuses in the entire election process because section 241 only extended to violations of a "right or privilege secured by" the Constitution.

The Court soon found that in certain respects the right to vote in congressional elections was constitutionally protected and thus

" Act of May 31, 1870, ch. 114, 16 Stat. 140.

- See text and notes at notes 110-22 infra.

10 Ex parte Siebold, 100 U.S. 371 (1879). The Court ruled that the federal government could exercise control over the election of its officials even though state officials were being elected in the same election. See Ex parte Yarbrough, 110 U.S. 651, 662 (1884); Ex parte Siebold, 100 U.S. 371, 387-93 (1879). 
within the coverage of section 241. In Ex parte Yarbrough," the defendants had been convicted under section 241 of conspiring to prevent a black man from casting a vote in a congressional election. The defendants argued before the Supreme Court that they had not violated a right secured by the Constitution because article I, section 2 of the Constitution ${ }^{12}$ gave the states control over voting qualifications for congressional elections. Rejecting that argument, the Court held that once a state established voting qualifications, persons meeting those qualifications were constitutionally entitled by article I, section 2 to cast their vote. ${ }^{13}$

In United States v. Mosley, ${ }^{14}$ the Supreme Court expanded the article I right to vote established in Yarbrough by holding that voters in congressional elections have a constitutional right to be free from certain forms of vote fraud. Affirming convictions under section 241 for refusing to count legally cast ballots in a congressional election, the Court found it "unquestionable that the right to have one's vote counted is as open to protection by Congress as the right to put a ballot in a box."15

Even though the Supreme Court had clearly stated that there was an article I right to vote, there was a good deal of confusion regarding the scope of this right. Some lower courts read Mosley as establishing only that each voter in a congressional election had a right to have his ballot counted: thus it was held that section 241 did not reach defendants who stuffed the ballot box with illegal ballots but were careful to make sure that every legal ballot was counted. ${ }^{16}$ However, the Supreme Court rejected this distinction in

11110 U.S. 651 (1884).

12 The House of Representatives shall be composed of members chosen . . . by the people of the several States, and the electors in each State shall have the qualifications requisite for electors of the most numerous branch of the State legislature.

13 Ex parte Yarbrough, 110 U.S. 651, 663-65 (1884). The Court also held that the fifteenth amendment prevented states from granting the right to vote to whites while withholding it from similarly qualified blacks. Id. at 664-65.

is 238 U.S. 383 (1915).

is Id. at 386.

1" See, e.g., Chavez v. United States, 261 F. 174 (8th Cir. 1919). This distinction was thought to be supported by language in United States v. Bathgate, 246 U.S. 220 (1918), where, in holding that bribery of congressional voters cannot be punished under section 241 , the Court suggested that section 241 protected only "personal" rights, and not the general, "political" interest in a fair election. Id. at 226-27. The Court in United States v. Saylor, 322 U.S. $385,388-90$ (1944), refused to apply this reasoning to vote fraud, and sharply questioned its continued validity in the bribery case. See text at notes 17-18 infra.

While Bathgate has never been overruled, bribery of voters in congressional elections is now an independent federal offense under 18 U.S.C. $\$ 597$ (1970). It has been held that Congress has no power to punish bribery in state elections. James v. Bowman, 190 U.S. 127 
United States v. Saylor, ${ }^{17}$ holding that, even though "[t]he mathematical result may not be the same," the "dilution" of legally cast ballots by ballot box stuffing also violated the article I, section 2 right to vote. ${ }^{18}$ In subsequent cases applying section 241 to vote fraud in congressional elections, the courts have continued to rely on the right to vote under article I, section 2, as elucidated in Mosley and Saylor. ${ }^{19}$

The Government cannot, however, rely on the article I, section 2 right to vote to prosecute under section 241 individuals alleged to have committed vote fraud in local elections. Article I, section 2 concerns only congressional elections; ${ }^{20}$ it is not the source of a right to vote in state or local elections. ${ }^{21}$ The states are free to determine voting qualifications and election procedures for their own elections subject to the restrictions on state action imposed by the fourteenth and fifteenth amendments. ${ }^{22}$ Thus, if prosecution for local vote fraud is possible under section 241 , it is likely to be based on an abridgement of the fourteenth or fifteenth amendments.

\section{B. Recent Expansions of the Constitutional Right to Vote}

Traditionally, it was thought that the fourteenth and fifteenth

(1903); see United States v. Bruno, 144 F. Supp. 593 (N.D. Ill. 1955); United States v. Foote, 42 F. Supp. 717 (D. Del. 1942). A commentator, however, has recently argued that the fourteenth amendment guarantees a right to "equality of political influence," which bribery would presumably violate. Fleischman, Public Financing of Election Campaigns: Constitutional Constraints on Steps Toward Equality of Political Infuence of Citizens, 52 N.C.L. Rev. $349,352-69$ (1973).

17322 U.S. 385 (1944).

1x Id. at 389 .

19 See, e.g., United States v. Classic, 313 U.S. 299 (1941) (vote fraud in congressional primaries also violates section 241); United States v. Morado, 454 F.2d 167 (5th Cir.), cert. denied, 406 U.S. 917 (1972); Fields v. United States, 228 F.2d 544 (4th Cir. 1955), cert. denied, 350 U.S. 982 (1956).

${ }^{20}$ Senatorial elections are governed by the nineteenth amendment, which contains language similar to that of article I, section 2 , Whether the right to vote in presidential elections is also secured by the Constitution, or whether electors are to be regarded as state officials (for purposes of section 241), is unclear. Article II, section 1 provides that electors shall be appointed by each state "in such Manner as the Legislature thereof may direct," and it has been held that when a state provides for choosing electors by popular vote, this method of election becomes a federally secured right through article II, section 1 . United States v. Buck, 18 F. Supp. 213 (W.D. Mo. 1937). However, the Eighth Circuit refused to follow this holding in Walker v. United States, 93 F.2d 383 (8th Cir. 1937), cert. denied, 303 U.S. 644 (1938), and the issue does not seem to have arisen since. But cf. Oregon v. Mitchell, 400 U.S. 112, 211-12, 291 (1970) (opinions of Harlan and Stewart, JJ.); Burroughs \& Cannon v. United States, 290 U.S. 534 (1934).

${ }^{21}$ See cases cited at note 25 infra.

${ }^{22}$ See text and note at note 32 infra. 
amendments only prohibited racially discriminatory activities..$^{23}$ Thus, the courts quickly established that the amendments prohibited denial of the right to vote in state elections on the basis of race and that Congress had the power to regulate state elections insofar as was necessary to prevent racial discrimination..$^{24}$ But the courts also held uniformly that these amendments did not confer the right to be protected from non-racially motivated vote fraud in state elections and consequently that such vote fraud could not be punished under section $241 .^{25}$

It has now become a commonplace that the equal protection clause of the fourteenth amendment does not forbid only racial discriminations. In Reynolds $v$. Sims, ${ }^{26}$ the Supreme Court held that geographic malapportionment of state legislative voting districts violates the equal protection clause. In reaching this conclusion, the Court used language that would suggest that local vote fraud does violate constitutional rights:

Undeniably the Constitution of the United States protects the right of all qualified citizens to vote, in state as well as in federal elections. A consistent line of decisions by this Court in cases involving attempts to deny or restrict the right of suffrage has made this indelibly clear. ${ }^{27}$

If the Constitution guarantees the right to vote in state as well as federal elections, then the decisions in Mosely and Saylor ${ }^{28}$ protect-

${ }^{23}$ See, e.g., The Slaughter-House Cases, 83 U.S. (16 Wall.) 36, 81 (1873).

24 Ex parte Yarbrough, 110 U.S. 651, 664-65 (1884); United States v. Lackey, 99 F. 952 (D. Ky. 1900), rev'd on other grounds, 107 F. 114 (6th Cir.), cert. denied, 181 U.S. 621 (1901); see James v. Bowman, 190 U.S. 127 (1903); United States v. Reese, 92 U.S. 214 (1875).

${ }_{25}$ Blitz v. United States, 153 U.S. 308 (1894); Ex parte Siebold, 100 U.S. 371, 393 (1879) (dictum); Walker v. United States, 93 F.2d 383 (8th Cir.), cert. denied, 303 U.S. 387 (1937); Steedle v. United States, 85 F.2d 867 (3d Cir. 1936); United States v. Kantor, 78 F.2d 710 (2d Cir. 1935); United States v. Nicholson, 27 F. Cas. 143 (No. 15) (C.C.D. La. 1878); cf. James v. Bowman, 190 U.S. 127 (1903); United States v. Bruno, 144 F. Supp. 593 (N.D. Ill. 1955); United States v. Foote, 42 F. Supp. 717 (D. Del. 1942) (congressional power to punish bribery extends only to federal elections).

In United States v. Reese, 92 U.S. 214 (1875), the Court struck down section 4 of the Enforcement Act of 1870, which protected the right to register to vote from obstruction by force, bribery, threats, intimidation, or other unlawful means, because on its face it covered purely local elections as well as federal elections. The Court refused to save the section by limiting its operations to federal elections or cases of racial discrimination, saying, "It would certainly be dangerous if the legislature could set a net large enough to catch all possible offenders, and leave it to the courts to step inside and say who would be rightfully detained, and who should be set at large." Id. at 221.

24377 U.S. 533 (1964).

${ }^{27}$ Id. at 554 (emphasis added).

2x See text and notes at notes 14-18 supra. 
ing the constitutionally based right to vote from vote fraud should apply with equal force to both state and federal elections. As if to confirm this conclusion, the Reynolds Court went on to observe:

[T] he right of suffrage can be denied by a debasement or dilution of the weight of a citizen's vote just as effectively as by wholly prohibiting the free exercise of the franchise. ${ }^{29}$

The difficulty with building on the dicta in Reynolds that there is a constitutionally protected right to vote in state elections is that the "consistent line of decisions" referred to in the opinion consists entirely of cases dealing either with racial discrimination in state elections or with the right to vote in federal elections under article $\mathrm{I} ;{ }^{30}$ the cases cited do not provide support for an absolute right to vote in state elections. It was not, moreover, necessary for the Court to reach that question in Reynolds. The issue for decision was not whether such an unqualified right to vote exists, but rather whether the equal protection clause requires that the state, once it grants the right to vote, must dispense that right in a nondiscriminatory fashion. Reynolds clearly holds that it does.

While some lower courts have spoken of Reynolds as establishing the right to vote, ${ }^{31}$ recent Supreme Court decisions have made it clear that the equal protection clause protects the right to participate "on an equal basis with other citizens," and not the right to vote per se..$^{32}$ These decisions constitute further support for the prop-

${ }^{29} 377$ U.S. 533, 555 (1964).

30 Cases cited $i d$. at 554-55.

31 See, e.g., Anderson v. United States, 481 F.2d 685, 699 (4th Cir. 1973), aff'd on other grounds, 417 U.S. 211 (1974); Smith v. Dunn, 381 F. Supp. 822, 824 (M.D. Tenn. 1974); League of Women Voters v. Fields, 352 F. Supp. 1053 (E.D. Ill. 1972); Kohler v. Tugwell, 292 F. Supp. 978, 981 (E.D. La. 1968), aff'd, 393 U.S. 531 (1969) (per curiam). Anderson and Fields are the only cases to make this suggestion in a vote fraud context, and in Fields the vote fraud apparently affected congressional as well as local races. $352 \mathrm{~F}$. Supp. at 1055 . See also note 7 supra.

${ }^{32}$ Dunn v. Blumstein, 405 U.S. 330, 336 (1972); see Oregon v. Mitchell, 400 U.S. 112 , 124-25 (1970) (Black, J.); Kramer v. Union Free School Dist. No. 15, 395 U.S. 621, 628-29 (1969); Sailors v. Board of Educ., 387 U.S. 105 (1966); Fortson v. Morris, 385 U.S. 231 (1966); Harper v. Virginia Bd. of Elections, 383 U.S. 663, 665 (1966). See also Minor v. Happersett, 88 U.S. (21 Wall.) 162 (1875). In reviewing several equal protection principles recently, the Court noted that

Since the right to vote [in state elections], per se, is not a constitutionally protected right, we assume that appellees' references to that right are simply shorthand references to the protected right, implicit in our constitutional system, to participate in state elections on an equal basis with other qualified voters whenever the State has adopted an elective process for determining who will represent any segment of the state's population.

San Antonio Ind. School Dist. v. Rodriguez, 411 U.S. 1, 35 n.78 (1973). See also id. at 59 n.2 (Stewart, J., concurring); Blassman v. Markworth, 359 F. Supp. 1 (N.D. Ill. 1973). 
osition that the constitutional violation in the apportionment cases lay in the fact that the votes cast in certain districts were weighted more heavily than votes cast in other districts, ${ }^{33}$ not in the "dilution" of individual citizens' votes. Consequently, local vote fraud can be brought within these holdings only upon a showing that some votes were given greater weight than others; a showing that the votes of legitimate voters were somehow "diluted" would be insufficient.

The problem with using this equal protection theory to prosecute local vote fraud under section 241 is that it would not reach all types of vote fraud. Where, for example, some ballots were discarded while the others were counted, there has been an equal protection violation because some voters have been treated unequally. The same may be true if the vote fraud is limited to certain precincts, affecting only voters in those areas. ${ }^{34}$ But section 241 could not be used where all the ballots were disregarded and fraudulent totals returned, or where the ballot box was stuffed with illegal ballots and all legal votes were "diluted" by the same proportion. Since no votes have been given unequal weight in either of these cases, ${ }^{35}$ there has been no violation of equal protection rights. ${ }^{36}$

${ }^{33}$ See, e.g., Gaffney v. Cummings, 412 U.S. 735, 740-42 (1973); Reynolds v. Sims, 377 U.S. 533, 562-64 (1964).

3s Cf. Ammond v. McGahn, 390 F. Supp. 655, 660 (D.N.J. 1975) (the exclusion of a state senator from her party's caucus unconstitutionally discriminated between her constituents and voters in other districts).

${ }^{35}$ It could be argued that the members of the vote fraud conspiracy had given their own votes greater weight than those of ordinary citizens, who did not participate in the vote fraud. However, to find a violation of equal protection rights because persons acting under color of state law unjustifiably treated themselves differently from other citizens would be to expand the equal protection clause beyond its current frontiers. For example, would a city treasurer who absconded with public funds be violating equal protection rights because he refused to let other citizens make similar thefts? $C f$. Snowden v. Hughes, 321 U.S. 1 (1944): "A construction of the equal protection clause which would find a violation of federal right in every departure by state officers from state law is not to be favored." Id. at 11-12.

${ }^{36}$ Cf. Heymann v. Louisiana, 269 F. Supp. 36, 42 (E.D. La. 1967): "If all citizens receive in the same circumstances the same treatment, then no citizen is denied his right to the equal protection of the laws, although all citizens might be receiving unfair treatment. When all are treated unfairly, no one is treated unequally." See also Miller v. Kusper, 445 F.2d 1059 (7th Cir. 1971); Ajello v. Schaffer, 349 F. Supp. 1168, 1174 (D. Conn. 1972) (election procedures equally harsh on all candidates do not violate equal protection rights).

It might be possible to find an equal protection violation in some of these cases, however, depending upon the way in which the ballot box was stuffed. For example, if the illegal votes were cast by allowing friendly voters to vote more than once, it could be argued that these voters were given unequal weights - thus introducing the curious principle of distinguishing cases on the basis of the number of ballots cast by each individual illegal voter. See also note 45 infra. Two points deserve mention, problems of proof aside. First, such artificial distinctions were abandoned in cases involving congressional elections. See text and notes at notes 
There may, however, be a way to view local vote fraud as an equal protection violation without regard to the method of the fraud. The apportionment cases focused on the mathematical weight given to each vote because the political effect of malapportionment is often speculative and difficult to determine ${ }^{37}$ The political effect of vote fraud, on the other hand, is evident: vote fraud gives one (or more) candidate (and his supporters) an unfair advantage over the others. In related areas, the Supreme Court has invalidated measures that cancelled out the political strength of certain groups. These decisions could be invoked to invalidate local vote fraud by focusing on this unequal political effect-on the rights of voters as political partisans instead of their rights as neutral voters. ${ }^{38}$

In cases involving multi-member legislative districts, for example, the Supreme Court has found a violation of the equal protection clause whenever such districting is used to "minimize or cancel out the voting strength of racial or political elements of the voting population." ${ }^{39}$ Similarly, the Supreme Court has held that statutes that make it more difficult for some candidates than others to get on the ballot violate equal protection..$^{40}$ Various lower courts, drawing on this reasoning, have found denials of equal protection in the mobilization of patronage workers to support "machine" candidates," and in the placing of official posters prominently displaying an incum-

14-18 supra. Second, the basic point still stands: the method by which the vote fraud was perpetrated will determine the applicability of section 241 under this equal protection principle.

${ }^{37}$ The Court in Reynolds $v$. Sims, however, suggested that malapportionment generally operated to favor rural areas over urban ones. 377 U.S. 533, 542 n.7, 567 n.43 (1964).

3* These restrictions, like vote fraud, can be viewed as discriminating either against the candidates themselves or against voters as supporters of injured candidates. As the Court observed in Bullock v. Carter, "the rights of voters and the rights of candidates do not lend themselves to neat separation; laws that affect candidates always have at least some theoretical, correlative effect on voters." 405 U.S. 134, 143 (1972); see Mancuso v. Taft, 476 F.2d 187 (1st Cir. 1973).

39 See White v. Regester, 412 U.S. 755, $765-70$ (1973); Whitecomb v. Chavis, 403 U.S. 124, 143 (1971), quoting Burns v. Richardson, 384 U.S. 73, 88 (1966), and Fortson v. Dorsey, 379 U.S. 433, 439 (1965); cf. Gaffney v. Cummings, 412 U.S. 735, 751-54 (1973).

to E.g., Bullock v. Carter, 405 U.S. 134 (1972) (high filing fees discriminating against poor candidates); Williams v. Rhodes, 393 U.S. 23 (1968) (petitioning requirements discriminating against minor parties). Williams $v$. Rhodes involved candidates for presidential electors, but there is no suggestion that different standards would apply to candidates for state and local office. The first amendment aspects of the Williams decision are discussed in the text and notes at notes 49-50 infra.

"Shakman v. Democratic Organization, 435 F.2d 267 (7th Cir. 1970), cert. denied, 402 U.S. 909 (1971); White v. Snear, 313 F. Supp. 1100 (E.D. Pa. 1970); see Brooks v. Nacrelli, 473 F.2d 955 (3d Cir. 1973). 


\section{bent's name at the polling places. ${ }^{42}$}

Although these cases have never been relied on to mount a constitutional challenge to vote fraud,,$^{43}$ the analogy is clear. There is little difference between reducing a group's political strength by submerging it in a larger legislative district or by keeping its candidates off the ballot, and reducing its strength by refusing to count the votes cast for it. The essence of the constitutional violation is the same in each case: official ${ }^{44}$ treatment which unjustifiably puts one political group at a disadvantage with respect to others. ${ }^{45}$

${ }^{42}$ Flamm v. Kusper, 384 F. Supp. 1364 (N.D. Ill. 1974). It has also been held that unintentional election irregularities (such as the counting of invalid ballots) do not violate equal protection rights precisely because there is no "purposeful discrimination." Hennings v. Grafton, 523 F.2d 861 (7th Cir. 1975); Pettengill v. Putnam County R-1 School Dist., 472 F.2d 121 (8th Cir. 1973); Powell v. Power, 436 F.2d 84 (2d Cir. 1970); Means v. Wilson, 383 F. Supp. 378 (D.S.D. 1974); cf. Snowden v. Hughes, 321 U.S. 1 (1944).

${ }^{13}$ In United States v. Classic, 313 U.S. 299 (1941), the Government argued that vote fraud in a congressional primary violated equal protection rights as well as the right to vote under article I. That argument, however, was raised for the first time on appeal, and the court declined to discuss it. Id. at 329.

"Where vote fraud in congressional elections is prosecuted on the theory of a violation of the right to vote under article I, state action need not be shown. Paynes v. Lee, 377 F.2d 61 (5th Cir. 1967); United States v. Ellis, 43 F. Supp. 321 (W.D.S.C. 1942). State action is usually required for any theory based on a violation of fourteenth amendment rights, but most methods of vote fraud require the cooperation of at least one election official and thereby satisfy the state action requirement. United States v. Classic, 313 U.S. 299, 325-26 (1941); Anderson v. United States, 481 F.2d 685, $698-700$ (4th Cir. 1973), aff'd on other grounds, 417 U.S. 211 (1974). There are no reported cases in which a prosecution failed because of an inability to show state action. But cf. Munoz v. Amador, 230 F. Supp. 591 (S.D. Tex. 1964), appeal dismissed as moot, 340 F.2d 590 (5th Cir. 1965).

In United States v. Guest, 383 U.S. 745 (1966) (applying section 241 to a denial of the right to equal utilization of state facilities), six Justices signed opinions suggesting that Congress can proscribe private conspiracies to abridge fourteenth amendment rights under section 5 of the fourteenth amendment. See id. at 762 (Clark, J. concurring), 778-81 (Brennan, $\mathrm{J}$, concurring and dissenting). But the Burger Court has so far declined to reach any decision on this point. See District of Columbia v. Carter, 409 U.S. 418, 424 n.8 (1973); Griffin v. Beckenridge, 403 U.S. 88, 107 (1971). Compare Action v. Gannon, 450 F.2d 1227 (8th Cir. 1971), with Bellamy v. Mason's Stores, Inc., 508 F.2d 504 (4th Cir. 1974), and Dombrowski v. Dowling, 459 F.2d 190 (7th Cir. 1972). For varying academic interpretations of the Guest opinions and their progeny, see Cox, The Role of Congress in Constitutional Determinations, 40 U. Cin. L. Rev. 199, $239-47$ (1971); Note, Federal Power to Regulate Private Discrimination: The Revival of the Enforcement Clauses of the Reconstruction Era Amendments, 74 Colum. L. Rev. 449, 510-17 (1974); Note, Fourteenth Amendment Congressional Power to Legislate Against Private Discriminations: The Guest Case, 52 ConNell L.Q. 586 (1967). See also Frantz, Congressional Power to Enforce the Fourteenth Amendment Against Private Acts, 73 YaLE L.J. 1353 (1964).

${ }_{13}$ The line between this theory and one focusing on weighting votes unequally is, admittedly, not always clear. For example, a district court recently struck down a statute allowing a territorial Governor to appoint five members of a city council otherwise composed of elected members. The decision rested on the proposition that this procedure gave those city residents who had voted for the Governor superior voting weight. Ortiz v. Hernandez Colon, 385 F. 
It would also be possible to view the political disadvantage caused by local vote fraud as a burden on the disadvantaged voters' closely related first amendment right to associate freely for the advancement of political ideas. ${ }^{46}$ It is well established that this is a fundamental right, protected from state interference by the due process clause of the fourteenth amendment; ${ }^{47}$ many election procedures no more burdensome than vote fraud have been held to violate this right. ${ }^{48}$ In Williams $v$. Rhodes ${ }^{49}$ the Court, in striking down petition requirements that made it virtually impossible for minor parties to qualify their candidates for the ballot, wrote:

The right to form a party for the advancement of political goals means little if a party can be kept off the election ballot and thus denied an equal opportunity to win votes. ${ }^{50}$

When organized vote fraud makes it substantially more difficult for a party's candidates to win, ${ }^{51}$ the burden imposed on the party may

Supp. 11 (D.P.R. 1974), stay pending filing of appeal granted, 421 U.S. 903 (1975), appeal filed, 44 U.S.L.W. 3031 (July 22, 1975). It seems more straightforward, however, to characterize the statute as simply giving the Governor's supporters an unjustifiable political advantage. No elections were held in which each citizen's vote was not weighted equally with every other citizen's; the problem was that (as with successful vote fraud) some councilmen were selected by the command of one political faction instead of by open elections.

${ }^{18}$ In most cases the difference between the equal protection and first amendment theories will be, at most, slight. Many of the decisions cited could have rested on both theories; several actually did. See, e.g., Williams v. Rhodes, 393 U.S. 23 (1968); Mancuso v. Taft, 476 F.2d 187 (1st Cir. 1973). Compare Bullock v. Carter, 405 U.S. 134 (1972), with Lubin v. Panish, 415 U.S. 709 (1974). For a general discussion of the relationship between inequality and first amendment rights, with special attention to the elections context, see Karst, Equality as a Central Principle in the First Amendment 43 U. CHI. L. REv. 20, 52-65 (1975). See also Developments in the Law-Elections, 88 HARv. L. REv. 1111, 1134-36 (1975).

17 Kusper v. Pontikes, 414 U.S. 51 (1973); Hadnott v. Amos, 394 U.S. 358 (1969); NAACP v. Button, 371 U.S. 415 (1963); NAACP v. Alabama ex rel. Patterson, 357 U.S. 449 (1958).

sk E.g., Lubin v. Panish, 415 U.S. 709 (1974) (filing fees); Kusper v. Pontikes, 414 U.S. 51 (1973) (restrictions on changing party registration); Williams v. Rhodes, 393 U.S. 23 (1968) (petition requirements for minor party candidates).

19393 U.S. 23 (1968).

${ }^{30} I d$. at 31 . The equal protection implications of the decision are discussed at notes 40 46 supra.

${ }^{51}$ It is generally held that minor restraints do not violate the first amendment right to political association. Compare Kusper v. Pontikes, 414 U.S. 51 (1973), with Rosario v. Rockefeller, 410 U.S. 752 (1973); and compare Williams v. Rhodes, 393 U.S. 23 (1968), with Jenness v. Fortson, 403 U.S. 431 (1971), and Storer v. Brown, 415 U.S. 724, 738-46 (1974). This is contrary to the rule adopted in congressional vote fraud cases, where it has been held that the article I, section 2 right to vote is violated by even an insignificant amount of vote fraud. Fields v. United States, 228 F.2d 544 (4th Cir. 1955), cert. denied, 350 U.S. 982 (1956); Prichard v. United States, 181 F.2d 326 (6th Cir.), aff'd for absence of a quorum, 339 U.S. 974 (1950); United States v. Skurla, 126 F. Supp. 713 (W.D. Pa. 1954). There is also no suggestion of a de minimis defense in the equal protection cases discussed earlier. 
be just as heavy as if the candidates had never been allowed on the ballot. In these circumstances, the rights violated by vote fraud include the rights of political association..$^{52}$

Although no court has yet passed on the question of whether local vote fraud violates the fourteenth amendment under one of the three theories considered here, ${ }^{53}$ a court could, in light of the development of these rights in other contexts, reasonably decide that it does. The more difficult question, examined in the next two sections, is whether local vote fraud can currently be punished under section 241.

\section{Problems of Vagueness}

Because section 241 punishes interference with "any right or privilege" secured by the Constitution, it would seem that once it can be concluded that local vote fraud violates a constitutional right it is also established that local vote fraud violates section 241 . However, if section 241 automatically encompassed each new logical development in constitutional law, it would "incorporate by reference a large body of changing and uncertain law" and expose defendants to uncertain liability. ${ }^{54}$ This section explores the problems caused by the indefiniteness of section 241 and the judicial attempts to resolve those problems.

Similarly, a de minimis defense in cases of local vote fraud could be inferred from recent apportionment decisions. The Supreme Court has allowed greater deviations in the relative populations of state legislative districts judged under the fourteenth amendment than it has in cases involving congressional districting under article I, section 2. Compare Mahan v. Howell, 410 U.S. 315 (1973), Gaffney v. Cummings, 412 U.S. 735 (1973), and White v. Regester, 412 U.S. 755 (1973), with White v. Weiser, 412 U.S. 783 (1973). See generally Casper, Apportionment and the Right to Vote: Standards of Judicial Scrutiny, 1973 Sup. Cr. Rev. 1. However, the lower standard in the state apportionment cases rests on the assumption that deviations from perfect equality are justified by legitimate state policies that federal courts should respect. See Mahan v. Howell, 410 U.S. 315, 325-26 (1973). This rationale clearly does not apply to a case of vote fraud.

52 Just how far the right to associate to advance political ideas extends in connection with state elections is not entirely settled; if carried to an extreme, it would guarantee the right to vote itself. This possibility was noted in passing by Justice Douglas, writing for the Court in Harper v. Virginia Bd. of Elections, 383 U.S. 663, 665 (1966), but later cases decided under the equal protection clause seem to deny the existence of any right to vote per se in state elections. See text and note at note 32 supra; cf. Ortiz v. Hernandez Colon, 385 F. Supp. 111, 117 n.5 (D.P.R. 1974), stay pending filing of appeal granted, 421 U.S. 903 (1975), appeal filed, 44 U.S.L.W. 3031 (July 22, 1975).

ss The circuit court's decision in Anderson v. United States, 481 F.2d 685 (4th Cir. 1973), aff'd on other grounds, 417 U.S. 211 (1974), was based on the belief that the reapportionment decisions established a right to vote per se in state elections. See id. at 699 . But see text and note at note 32 supra.

34 Screws v. United States, 325 U.S. 91, 96 (1945). 


\section{A. Screws v. United States}

The doctrine that vague penal statutes violate the constitutional requirements of due process has been called, with cause, "[o]ne of the more perplexing judicial doctrines." 55 The doctrine serves a number of purposes, ${ }^{56}$ but the original and most basic is to ensure that the statute gives fair warning of the conduct it proscribes. ${ }^{57}$ Though the doctrine may be based on an unrealistic estimation of the extent to which potential criminals in fact know the law, ${ }^{58}$ it is now well established that "a statute which either forbids or requires the doing of an act in terms so vague that men of common intelligence must necessarily guess at its meaning and differ as to its application, violates the first essential of due process of law." 59

Whether any particular statute is too indefinite to enforce under this test is never a clear-cut matter: as Justice Frankfurter has noted, "indefiniteness" is itself an indefinite concept. "The Supreme Court, however, has long been wary of so-called "accordion" statutes that (like section 241) vary in scope in relation to changing interpretations of the Constitution. ${ }^{61}$ When 18 U.S.C. $\S$ 242 was challenged in Screws $v$. United States ${ }^{62}$ on the grounds of

${ }^{35}$ Collings, Unconstitutional Uncertainty-An Appraisal, 40 CoRnElL L.Q. 195 (1955).

${ }^{56}$ See generally Amsterdam, The Void-for-Vagueness Doctrine in the Supreme Court,

109 U. PA. L. REv. 67 (1960) [hereinafter cited as Amsterdam].

57 See Amsterdam, supra note 56, at 85-86. Another major purpose of the doctrine is to control the scope of discretion accorded enforcement agencies. See id. at 87-96. Another may be to enable the defendant adequately to prepare his defense. See id. at 67-68 n.3.

5x "[I]t is not likely that a criminal will carefully consider the text of the law before he murders or steals." McBoyle v. United States, 283 U.S. 25, 27 (1931) (Holmes, J.). See also Amsterdam, supra note 56 , at $82 \mathrm{n} .79$. It may be that election officials are more likely to be aware of the law than most criminals, cf. Screws v. United States, 325 U.S. 91, 129 (1945) (Rutledge, J., concurring in result), but it is still difficult to speak of a lack of fair warning when the act (as in the case of vote fraud) is unquestionably a crime under state law. However, the Court in McBoyle invoked a related principle (strict construction of penal statutes) even though the offense there was also a state crime. See also Screws v. United States, 325 U.S. 91, 108 (1945) ("Violation of local law does not necessarily mean that federal rights have been invaded.").

39 Connally v. General Constr. Co., 269 U.S. 385, 391 (1926). For alternate formulations, see, e.g., Grayned v. City of Rockford, 408 U.S. 104, 108 (1972); United States v. Harriss, 347 U.S. 612, 617 (1954); Lanzetta v. New Jersey, 306 U.S. 451, 453 (1939).

so Winters v. New York, 333 U.S. 507, 524 (1948) (Frankfurter, J., dissenting).

"In Smith v. Cahoon, 283 U.S. 553 (1931), the Court wrote:

The legislature could not thus impose upon laymen, at the peril of criminal prosecution, the duty of . . . resolving important constitutional questions with respect to the scope of a field of regulation as to which even courts are not yet in accord.

Id. at 564. See also United States v. Reese, 92 U.S. 214, 221 (1875), discussed at note 25 supra. See generally Amsterdam, supra note 56, at 76-80, 84; Lyon, Old Statutes and New Constitution, 44 Colum. L. Rev. 599 (1944).

${ }^{62}$ Screws v. United States, 325 U.S. 91 (1945). 
indefiniteness, the Court noted the "serious character of that challenge." 63

Three of the justices voted to hold that section 242 was unconstitutionally indefinite, ${ }^{64}$ but the majority saved the statute by reading a dual requirement into the word "willfully" so that a person would not be subject to criminal liability simply because an act was later determined to be in violation of the Constitution. ${ }^{65}$ The Court held that willfully committing an act that was in fact unconstitutional was not sufficient for conviction: instead, there had to be " $a$ specific intent to deprive a person of a federal right," 66 and that right must have "been made specific either by the express terms of the Constitution or laws of the United States or by decisions interpreting them." ${ }^{67}$ Since these requirements have subsequently been read into section $241,{ }^{68}$ it is necessary to examine the way in which they have been applied over the years to determine if local vote fraud can currently be punished under section 241 .

\section{B. The Requirement of Specific Intent}

The Court in Screws did not carefully define its understanding of the meaning of "specific intent" for the purposes of the statute. The Court clearly rejected the ordinary standard of guilt, simple

63 Id. at $95-96$.

" Id. at 138 (Roberts, Frankfurter, \& Jackson, JJ., dissenting).

"5 The term "willfully" was not included in the original predecessor to section 242. See Act of May 31, 1870, ch. 114, $\S 17,16$ Stat. 144. During House consideration of the Criminal Code of 1909 (codifying the criminal laws), Rep. Webb proposed inserting "willfully" into the statute. He feared that public officials might otherwise be found guilty of criminal behavior for mere errors of law; he also believed that every criminal law should have some scienter requirement. The House accepted the change by unanimous consent, without discussion. 42 CoNG. REc. 648 (1908). Although the conference committee report did not mention the change, Senator Daniel briefly noted that "willfully" had been inserted, "thus making [the statute] less severe." 43 ConG. REc. 3692 (1909). The statute in this form was enacted as section 20 of the Act of Mar. 4, 1909, ch. 321, 35 Stat. 1092.

“ Screws v. United States, 325 U.S. 91, 103 (1945) (emphasis added).

${ }^{17}$ Id. at 104 (emphasis added).

" In United States v. Williams, 341 U.S. 70 (1951), Justice Frankfurter, joined by three other justices, noted that section 241 , unlike section 242 , does not require the defendant to act "willfully." He argued from this that section 241 would be unconstitutionally vague if it were held to encompass fourteenth amendment rights. Id. at 82 . Justice Douglas, also joined by three justices, argued that the requirement of a "conspiracy" in section 241 imports the same intent requirement that "willfully" supplies to section 242 , and that section 241 should therefore be held to encompass fourteenth amendment rights. Id. at 93-95. Justice Black voted with Justice Frankfurter's group to make a majority, but on other grounds. Id. at 85 . The split was resolved fifteen years later when a majority of the Court adopted the view advanced by Justice Douglas in Williams. United States v. Price, 383 U.S. 787, 796-807 (1966) (due process clause); United States v. Guest, 383 U.S. 745, 753 (1966) (equal protection clause); accord, Anderson v. United States, 417 U.S. 211, 223 (1974). 
intent to do an act which is in fact unlawful, ${ }^{69}$ and expressly imposed a stricter standard. In order to be validly convicted, the Court wrote, a defendant must have had the purpose of depriving his victim of a constitutional right. ${ }^{70}$ However, the defendant need not have "been thinking in constitutional terms," 71 and acting in "reckless disregard of constitutional prohibitions" could apparently be adequate grounds for conviction. ${ }^{72}$ The intent necessary to support a conviction under section 242, and now section 241 as well, apparently lies somewhere indefinably between a mere intent to do the act done and an intent formed with specific reference to the constitutional rights involved.

The lower courts, not surprisingly, have had difficulty applying this vague standard or clarifying the reach of section 241 . It has generally been held permissible to assume that the defendant intended the consequences of his intentional acts, so if an act that the defendant intended to perform had the consequence of violating someone's constitutional rights, the defendant can be presumed to have intended that violation. ${ }^{73}$ Although the presumption technically appears to be rebuttable, the courts have found the requisite intent even where the defendant was motivated by passion ${ }^{74}$ or by an honest belief that he was following the legitimate and constitutional orders of his superior. ${ }^{75}$ These cases suggest that the intent requirement is presumptively satisfied whenever the defendant intentionally acted in a way that in fact violated a constitutional right. $^{76}$ Yet it was this very standard that the Court in Screws rejected. ${ }^{77}$

In vote fraud cases under section 241 , the specific intent re-

${ }^{69}$ Screws v. United States, 325 U.S. 91, 96-98 (1945) (rejecting the rule of Ellis v. United States, 206 U.S. 246 (1907)).

${ }^{70}$ Screws v. United States, 325 U.S. 91,107 (1945).

"Id. at 106.

${ }^{72}$ Id.

${ }^{73}$ United States v. Ragsdale, 438 F.2d 21 (5th Cir. 1971); United States v. Nathan, 238 F.2d 401 (7th Cir. 1956), cert. denied, 353 U.S. 910 (1957); Koehler v. United States, 189 F.2d 711 (5th Cir.), cert. denied, 342 U.S. 852 (1951); Crews v. United States, 160 F.2d 746 (5th Cir. 1947).

7 United States v. Delerme, 457 F.2d 156 (3d Cir. 1972); Crews v. United States, 160 F.2d 746 (5th Cir. 1947). But see United States v. Shafer, 384 F. Supp. 496 (M.D. Ohio 1974).

${ }^{75}$ United States v. Konovsky, 202 F.2d 721 (7th Cir. 1953); United States v. Ehrlichman, 376 F. Supp. 29 (D.D.C. 1974).

${ }^{76}$ See Note, May the Intent to Violate the Federal Civil Rights Statutes be Established by a Presumption? 40 GEo. L.J. 566 (1952).

7 See Monroe v. Pape, 365 U.S. 167, 207 (1961) (Frankfurter, J., dissenting in part); Koehler v. United States, 342 U.S. 852 (1951) (Jackson, J., dissenting from denial of certiorari). 
quirement has not played an effective role on appeals of convictions: no conviction has ever been reversed for lack of specific intent, and the Supreme Court has upheld the convictions of those who intended to have false votes cast, "whatever their motive."78 In other areas under section 241, courts have usually done little more than paraphrase Screws in their jury instructions, thus leading Justice Frankfurter to conclude that the effect has been to "needlessly burden jurors with abstruse instructions, and lessen the degree of control which federal courts have over jury vagaries," 79 without really reducing the indefiniteness of section $241 .{ }^{80}$ The discernible major

${ }^{7 \times}$ Anderson v. United States, 417 U.S. 211, 226-27 (1974). See also United States v. Nathan, 238 F.2d 401 (7th Cir. 1956), cert. denied, 353 U.S. 910 (1957).

The petitioners in Anderson were convicted under an indictment that charged them with conspiracy to cast false ballots in state and federal primary elections. The proof at trial showed that, although the objective of the conspiracy was to affect the state election, false votes were also cast for the federal offices. See note 7 supra. In his instructions to the jury, the trial judge did not distinguish between an intent to cast false votes in federal elections and in state elections.

Justice Marshall, writing for the Court, thought it irrelevant "that the primary motive behind [petitioners'] conspiracy was to affect the result in the local rather than the federal election" because "[a] single conspiracy may have several purposes, but if one of them-whether primary or secondary-be the violation of a federal law, the conspiracy is unlawful under federal law." 417 U.S. at 225-26. Stating that "[t]he specific intent required under $\S 241$ is not the intent to change the outcome of a federal election, but rather the intent to have false votes cast . . .," id., the Court affirmed the conviction because petitioners had not requested a limiting instruction at trial. The Court further held that no "plain error" could be found, finding "it inconceivable that, even if charged by more specific instructions, the jury could have found a conspiracy to cast false votes for local offices without finding a conspiracy to cast false votes for the federal offices as well." Id. at 228.

Justice Douglas, dissenting for himself and Justice Brennan, took issue with the last conclusion. Arguing that the case had been tried on the theory that fraud in the local election would violate section 241 , Justice Douglas thought the evidence of intent to cast false ballots in the federal election was not so conclusive as to justify the majority's refusal to find "plain error" in the trial judge's failure to instruct that intent to cast false votes in federal, as distinguished from state, elections was required to convict. Id. at 229.

Compare Justice Marshall's statement in Anderson that the primary purpose of the conspiracy need not be violation of federal rights with the statement in United States v. Guest, 383 U.S. 745, 760 (1966) that:

[Not] every criminal conspiracy affecting an individual's right of free interstate passage is within the sanction of 18 U.S.C. $\$ 241$. . . [F]or example, a conspiracy to rob an interstate traveler would not, of itself, violate $\$ 241$. But if the predominant purpose of the conspiracy is to impede or prevent the excercise of the right of interstate travel, . . . the conspiracy becomes a proper objection of [section 241].

7 Monroe v. Pape, 365 U.S. 167, 207 (1961) (Frankfurter, J., dissenting in part). One decision in that case was not to apply the same requirements to the civil counterpart of section 241, 42 U.S.C. $\$ 1983$ (1970). 365 U.S. at 187.

For an example of the confusion caused by the specific intent requirements, examine the jury instructions challenged and upheld in Apodaca v. United States, 188 F.d 932, 937-38 (10th Cir. 1951).

*o The requirement may have had the effect of excusing State officials who acted with innocent motives, but prosecutions are rarely brought in such cases. See United States v. 
impact of the specific intent requirement has been an unintended one: the requirement seems to reduce the effectiveness of the statute by providing another way for local juries to acquit defendants when federal enforcement is unpopular. ${ }^{81}$

The fact that the specific intent requirement of Screws has become a mere formality does not mean that section 241 is now unconstitutionally indefinite, for this aspect of the Screws requirement was probably never needed to satisfy that test. ${ }^{82}$ The vagueness doctrine only requires that the statutory prohibition be sufficiently definite to provide fair warning to those who seek it..$^{83}$ It does not also require that the defendant himself have actually had that warning. ${ }^{84}$ The requirement of specific intent, whatever it now means, has no bearing on whether the statute was sufficiently definite to provide a fair warning, and there is no need to continue even the formality of this requirement. In any case, it is clear that the specific intent requirement will not bar a prosecution under section 241 for local vote fraud. ${ }^{85}$

Trunko, 189 F. Supp. 559 (E.D. Ark. 1960); cf. Screws v. United States, 325 U.S. 91, 97 (1945); note 65 supra.

s1 See U.S. Comm'n on Civil Rights, Law Enforcement: A Report on Equal Protection IN THE South 108-09, 118 (1965); Clark, A Federal Prosecutor Looks at the Civil Rights Statutes, 47 Colum. L. REv. 175, 182-84 (1947); Shapiro, Limitations in Prosecuting Civil Rights Violations, 46 CoRNELL L.Q. 532 (1961). See also United States v. Guest, 383 U.S. 745, 786 (1966) (Brennan, J., concurring and dissenting). Screws himself, a Southern sheriff charged with beating a black prisoner to death, was acquitted on retrial under the "specific intent" instructions. Gressman, The Unhappy History of Civil Rights Legislation, 50 MicH. L. REv. 1323, 1353 (1952).

${ }^{82}$ The Screws Court itself conceded that "willful conduct cannot make definite that which is undefined." 325 U.S. at 105.

${ }^{83}$ Note, Due Process Requirements of Definiteness in Statutes, 62 HARv. L. REv. 77, 80 (1948); Note, State Police, Unconstitutionally Obtained Evidence and Section 242 of the Civil Rights Statute, 7 Stan. L. REv. 76, 85 (1954) [hereinafter cited as Stanford Note].

${ }^{84}$ If the vagueness doctrine required, in addition to the availability of fair notice, actual notice that particular conduct is prohibited, then ignorance of the law would be embodied as a constitutional defense. See Screws v. United States, 325 U.S. 91, 113 (Rutledge, J., concurring in result); Id. 134 (Murphy, J., dissenting) (1945). Justice Rutledge concurred in the result reached by the Court only to prevent a deadlock: he would have preferred to require only that the right in question be one that had been clearly established. Id. at 133-34. This view has received much support from commentators on the case. See Cohen, The Screws Case: Federal Protection of Negro Rights, 46 Colum. L. REv. 94, 104 (1946); Note, May the Intent to Violate the Federal Civil Rights Statute Be Established by a Presumption? 40 Geo. L.J. 566, 572-73 (1952); StanroRd NoTE, supra note 83, at 82-83.

${ }_{85} 18$ U.S.C. $\S 245$ (1970) was passed in order better to protect certain constitutional rights by relaxing the specific intent requirement which was thought to have hindered prosecutions under sections 241 and 242. 113 CoNG. REc. 22680 (remarks of Rep. Celler); 114 Cong. REc. 335 (remarks of Senator Kennedy), 1990-91 (remarks of Senator Fong) (1968). Subsection (b) of the statute punishes anyone who

whether or not acting under color of law, by force or threat of force willfully injuries 


\section{The Requirement of a Right Made "Definite and Certain"}

Even though the vagueness doctrine does not require the "specific intent" standard, the holding in Screws that a person can be punished under section 241 for violating another's constitutional rights only when the right has been made specific by legislation or prior decision is of constitutional dimension and should be respected. Acknowledging, as it had to, that constitutional doctrine changes over time, the Court in Screws was unwilling to cast citizens adrift "at their own risk on a vast uncharted sea" 86 by permitting criminal punishments to be imposed for violating emerging constitutional rights before they were made specific. Under this standard, the state of constitutional law with respect to the right to vote in state and local elections, as discussed in Part I above, is sufficiently unsettled that, at present, vote fraud in local elections should not be punishable under section 241 .

The salient facts for this discussion are these: (1) a host of decisions that have never been overruled hold that local vote fraud does not violate any constitutional right, ${ }^{87}$ even though the reapportionment cases and other recent decisions perhaps undermine these early holdings; ${ }^{88}(2)$ only one court has ever held that local vote fraud violates a constitutionally secured right and hence section $241 ;^{89}$ after granting certiorari in that case on that very issue, the Supreme Court, over dissent, resolved the case on other grounds; ${ }^{80}$

[sic], intimidates, or interferes with, or attempts to injure, intimidate or interfere with-(1) any person because he is or has been [exercising specified rights]; or (2) any person because of his race, color, religion or national origin and because he is or has been [exercising certain other rights] .... .

In the only opinion which has discussed the intent requirement under section 245 , the Eighth Circuit held that the defendant must have intended to prevent an individual from enjoying the facility in question, but the court invoked the presumption that the defendant intended the natural and probable consequences of his act to supply that finding. United States v. Price, 464 F.2d 1217 (8th Cir.), cert. denied, 409 U.S. 1040 (1972). The court did not intimate that the defendant had to have known that the activity in which his victim was engaged was constitutionally protected. See S. REP. No. 721, 90th Cong., 1st Sess. 9 (1967).

Section 245 no doubt represents Congress's response to the Court's repeated invitations to escape the scienter and specificity limitations read into section 241 . See, e.g., Screws v. United States, 325 U.S. 91, 105 (1945).

*s Screws v. United States, 325 U.S. 91, 98 (1945).

*7 Cases cited at note 25 supra.

${ }^{2 x}$ Text and notes at notes 26.53 supra.

" Anderson v. United States, 481 F.2d 685, 699 (4th Cir. 1973), aff'd on other grounds, 417 U.S. 211 (1974); see United States v. Stollings, 501 F.2d 954, 955 (4th Cir. 1974).

"Anderson v. United States, 417 U.S. 211 (1974); see note 7; text and note at note 78 supra. The Seventh Circuit similarly has avoided decision on the issue. United States v. Bradberry, 517 F.2d 498, 499 (7th Cir. 1975) (Stevens, J.). 
(3) finally, both Congress and the Department of Justice are still in doubt whether Congress has the power to punish vote fraud in local elections directly. ${ }^{91}$ Taking the Screws test at face value suggests that since there is not a clear constitutional right to vote in state and local elections section 241 cannot yet be applied to cases of local vote fraud.

Surprisingly, very few section 241 cases since Screws was decided in 1945 have discussed whether the constitutional right that had been violated had previously been made sufficiently specific to meet the Screws test. ${ }^{92}$ It is therefore somewhat difficult to tell if the courts, as with the specific intent requirement, have watered down the meaning of specificity.

Only once has a lower court reversed a section 241 conviction on the ground that the right in question had not been made sufficiently specific to meet the Screws test. In United States v. O'Dell, ${ }^{93}$ the Sixth Circuit refused to apply section 241 to the right to reasonable bail in a state criminal case even though the right had been recognized by two circuit court and six district court decisions and was supported by the reasoning of a Supreme Court decision..$^{94}$ If the $O ' D e l l$ case could be relied on as typical, there would be little doubt that section 241 does not now cover local vote fraud; the right to be free from vote fraud in local elections is surely not as well established as was the right in O'Dell. Unfortunately, O'Dell may not be typical; the few other lower court decisions which have considered

"As to Congress's doubts, see text and notes at notes 129, 133 infra. In 1973 the Justice Department advised Congress that local vote fraud did not violate the Constitution and could not be prosecuted under section 241. Hearings on Reform of the Federal Criminal Law's Before the Subcomm. on Criminal Law and Procedures of the Senate Comm. on the Judiciary, 93d Cong., 1st Sess., pt. 9, at 6780-81, 6784-85 (1973). By way of comparison, the National Commission on Reform of Federal Criminal Laws apparently concluded that local vote fraud did violate constitutional rights (and section 241), although the Consultant to the Commission viewed the issue as not yet settled. Compare Nat'l Comm'N on REForm of Fed. Criminal Laws, Final Report 163-64 (1971), with 2 Nat'l Comm'n on Reform of Fed. Criminal Laws, Working Papers 813 (1970) [hereinafter cited as Working Papers].

${ }^{92}$ This scarcity may be due in part to the Justice Department's apparent hestitation to prosecute under section 241 when there is any doubt regarding the ultimate success of the prosecution. See generally Clark, supra note 81.

${ }^{33} 462$ F.2d 224 (6th Cir. 1972).

" Id. at 230, citing United States ex rel. Keating v. Bensinger, 322 F. Supp. 784, 786 n.3

(D. Ill. 1971). The O'Dell court stated:

Th Screws test of course eliminates the possibility that persons may be prosecuted for willful violation of "emerging" Constitutional rights. While lessening the scope of civil rights protection available to citizens, such limitation is necessary if the criminal civil rights statutes are themselves to avoid characterization as unduly vague and indefinite.

462 F.2d at 230 n.7. 
the requirement have had no difficulty finding the right involved to be sufficiently specific. ${ }^{95}$

The Supreme Court also has had very few opportunities to demonstrate whether it intends to honor the specificity requirement. In United States $v$. Guest $t^{96}$ the Court treated the requirement somewhat cavalierly, upholding an indictment alleging that private persons had violated the constitutional "right to interstate travel," even though no prior case had ever recognized a right to be free from private interference. ${ }^{97}$ Furthermore, in 1966 the Court increased the possibility that a conviction under section 241 would be based on a right not yet made specific by holding that violations of the fourteenth amendment came within section 241's proscription. ${ }^{98}$ But, it must be emphasized, the Court did not in that holding retreat from the Screws standard of specificity, nor has it done so in any other case.

If the courts have not been vigorous enough in expressing their allegiance to the specificity requirement of section 241 to inspire confidence, a line of civil cases brought under 42 U.S.C. \& 1983, 9 the civil counterpart of section 241, suggests that the specificity requirement is still vital. In Pierson v. Ray, ${ }^{100}$ the Court established the doctrine that the constitutional right allegedly violated by the defendant in a section 1983 action must be one that was judicially recognized at the time of the violation. In Pierson, the Supreme Court reversed a judgment against certain police officers for making an arrest under a statute that the Court later found to be unconsti-

${ }^{97}$ United States v. Stokes, 506 F.2d 771 (5th Cir. 1975) (right not to be beaten before trial); United States v. Cooney, 217 F. Supp. 417 (D. Colo. 1963) (fourteenth amendment right to be free from unreasonable search and seizure); United States v. Wilson, 72 F. Supp. 812 (W.D. Mo. 1947) (vote fraud in a congressional primary). For an argument that the right involved in Cooney was not sufficiently specific to justify prosecution after section 241 , see STANFord Note, supra note 83, at 89-95. That Note also argues that the right in Screws was not sufficiently specific. Id. at 84-85.

" 383 U.S. 745 (1966).

"Id. at 759-60 n.17. See also Justice Harlan's dissent on this point. Id. at 762-74. The majority stated that, although the Court had never decided whether the right to travel was protected against private interference, nonetheless the reasoning of prior cases supported such a holding. Id. at 759-60 n.17. To say that a holding protecting a new right is supported by reasoning in prior cases does not take one very far in deciding whether the right previously was "specific," for the Court can find reasoning in prior cases in support of every new holding.

* United States v. Price, 383 U.S. 787, 796-807 (1966) (due process clause); United States v. Guest, 383 U.S. 745, 753 (1966) (equal protection clause); see note 68 supra.

" "Every person who, under color of any statute, ordinance, regulation, custom, or usage, of any State or Territory, subjects, or causes to be subjected, any citizen of the United States or other person within the jurisdiction thereof to the deprivation of any rights, privileges, or immunities secured by the Constitution and laws, shall be liable to the party injured . . . ."

${ }^{100} 386$ U.S. 547 (1967). 
tutional. The Court wrote that a policeman should be excused "from liability for acting under a statute that he reasonably believed to be valid but that was later held unconstitutional .... [A] police officer is not charged with predicting the future course of constitutional law."101

Since Pierson, when a case has turned directly on the status of the constitutional right at the time of the defendant's actions, the requirement of prior specificity has usually been applied strictly. ${ }^{102}$ Recovery has been denied where the right in question had been recognized only by lower courts in another circuit ${ }^{103}$ or when the Supreme Court had spoken on the issue without resolving it. ${ }^{104} \mathrm{Re}$ covery has also been denied when the right in question was first recognized after the defendant's alleged violation but before his trial, ${ }^{105}$ or when the right in question had not yet been "enunciated by a court in a manner which makes its applicability to the incident at hand clear." 106 If applied to section 241 , none of these formulations of the specificity test would permit prosecution for local vote fraud under section 241 at the present time.

Since the courts have adhered to the specificity requirement in section 1983 civil actions, it seems probable that they would do likewise in section 241 criminal actions if put to the test: there is no reason to require a lower degree of clarity of constitutional rights under section 241 than under section 1983. The question in each

${ }^{101}$ Id. at 555-57. See also Wood v. Strickland, 420 U.S. 308, 321-22 (1975) (emphasis added).

[A]n act [by a school official] violating a student's constitutional rights can be no more justified [under $\$ 1983$ ] by ignorance or disregard of settled, indisputable law . . . than by the presence of actual malice. . . . [A] school board member . . . must be held to a standard of conduct based not only on permissible intentions, but also on knowledge of the basic, unquestioned constitutional rights of his charges.

${ }^{102}$ The case law is often confusing, as the test is usually subsumed under a general "good faith" requirement, which can also include the issue of whether the particular defendant actually believed his acts were constitutional, the issue of good faith as defining the limits of official immunity from suit, and the considerations (not present in vote fraud cases) of not unduly hampering legitimate law enforcement efforts. But see Williams v. Johnson, $386 \mathrm{~F}$. Supp. 280, 288-89 (D. Md. 1974) (applying the same test to a non-official defendant who was performing no law enforcement functions).

${ }^{103}$ Anderson v. Nosser, 438 F.2d 183, 194-95 (5th Cir. 1971), modified on other grounds, 456 F.2d 835 (en banc), cert. denied, 409 U.S. 848 (1972); Huotari v. Vanderport, 380 F. Supp. 645, 652 (D. Minn. 1974); Urbano v. McCorkle, 346 F. Supp. 51, 54 (D.N.J. 1972), aff'd, 481 F.2d 1400 (3d Cir. 1973).

10s Williams v. Gould, 486 F.2d 547, 548 (9th Cir. 1973); Huotari v. Vanderport, 380 F. Supp. 645, 652 (D. Minn. 1974); Baxter v. Birkins, 311 F. Supp. 222, 225 (D. Colo. 1970).

${ }_{105}$ Bauer v. Sielaff, 372 F. Supp. 1104, 1108 (E.D. Pa. 1974), appeal dismissed as moot, 510 F.2d 969 (3d Cir. 1975); Young v. Coder, 346 F. Supp. 165, 169 (M.D. Pa. 1972).

${ }^{108}$ Bowens v. Knazze, 237 F. Supp. 826, 829 (N.D. Ill. 1965). 
instance is whether the right alleged to have been violated had been spelled out with sufficient specificity in prior judicial decisions to justify holding that the defendant, had he been so inclined, could have ascertained that the right existed. In fact, it can be plausibly argued that a higher standard of specificity should apply under section 241 than under the civil statute because of our legal system's traditional concern with protecting individuals from improper criminal punishment. ${ }^{107}$ If the specificity-of-rights requirement under section 241 is as healthy as it seems, then the conclusion advanced before ${ }^{108}$ is sound: vote fraud in local elections could not yet be held to violate section 241 . If the specificity requirement is no longer being followed then the Screws requirements have been completely eroded, and section 241 is again vulnerable to charges of unconstitutional uncertainty.

\section{Congressional Intent and Local Vote Fraud}

A problem related to vagueness that would arise if section 241 were expanded to punish local vote fraud is the risk that federal criminal law would be punishing conduct that Congress intended to leave to state control. Although the risk of going beyond legislative intent is present whenever the courts construe criminal statutes, the potential for overexpansion is greater with an "accordion statute," the scope of which changes with each judicial interpretation of the Constitution. This section examines the extent of this problem and possible methods of limiting section 241 to avoid it.

\section{A. The Legislative History of Section 241}

In his dissent in Anderson $v$. United States, ${ }^{109}$ Justice Douglas claimed that the legislative history of section 241 shows that Congress never intended that the section would cover local vote fraud.

${ }^{107}$ In announcing the standard of intent required under section 1983 to be applied to police conduct, the Court thought it was using a more relaxed standard of intent than it used in section 241 cases:

In the Screws case we dealt with a statute that imposed criminal penalties for acts "willfully" done. We construed that word . . . to mean the doing of an act with "a specific intent to deprive a person of a federal right." 325 U.S., at 103 . We do not think that gloss should be placed on $\S[1983]$.... [It] provides a civil remedy, while in the Screws case we dealt with a criminal law challenged on the ground of vagueness. Section [1983] should be read against the background of tort liability that makes a man responsible for the natural consequences of his actions.

Monroe v. Pape, 365 U.S. 167, 187 (1961).

${ }^{10 x}$ See text and note at note 91 supra.

10 417 U.S. 211, 228 (1974) (Douglas, J., dissenting). 
One difficulty with his argument is that the history of section 241 is anything but clear.

Section 241 was introduced as a floor amendment to the Enforcement Act of $1870,{ }^{110}$ an act designed to provide federal enforcement of the fifteenth amendment right to vote and to impose criminal penalties for certain specified offenses relating to congressional elections. Although proposed section 241 was the only provision of the Act that dealt with "any right or privilege" secured by the Constitution, ${ }^{111}$ the potential breadth of this broad language went virtually unnoticed by both houses of Congress. Senator Pool himself, the sponsor of the section, was unclear as to the scope of rights that the section was intended to cover. At one point he suggested that section 241 was designed to remedy a flaw in section 4 of the Act by reaching conspiracies aimed at violating fifteenth amendment rights. ${ }^{12}$ At another point he spoke of protecting both fourteenth and fifteenth amendment rights, apparently including rights other than voting; ${ }^{113}$ while at yet another point he spoke broadly of the federal government going "into the States for the purpose of securing and protecting the liberty of the citizen and the rights and immunities of American citizenship." ${ }^{114}$ Senator Bayard, in the final debate on the Enforcement Act, took Senator Pool at his broadest word and criticized the legislature for not specifying the wrongs covered by section $241 .^{115}$

110 The current section 241 was introduced as section 6 of the original act. Act of May 31,1870 , ch. $114, \S 6,16$ Stat. 141.

III Other sections of the Enforcement Act protected the right to vote from racial discrimination in all elections (section 1); the right to do any act required to qualify to vote (sections 2 and 3 ); the right to register (section 4) and vote (section 5) in all elections free from obstruction by force, bribery, threats, intimidation, or other unlawful means. (Section 4 was held unconstitutional in United States v. Reese, 92 U.S. 214, 220-22 (1875). See note 25 supra.) The Act provided penalties for false registration and voting in elections for federal office (sections 19 and 20).

112 Cong. GloBE, 41st Cong., 2d Sess. 3611 (1870) [hereinafter cited as Globe], reprinted as an appendix to United States v. Price, 383 U.S. 787, 807-20 (1966). See also GLoBE at 3685 (remarks of Senator Howard and Senator Stewart).

113 [I]ndividuals may prevent the exercise of the right of suffrage; individuals may prevent the enjoyment of other rights which are conferred upon the citizen by the fourteenth amendment, as well as trespass upon the right conferred by the fifteenth.

GLOBE, supra note 112, at 3611 (remarks of Senator Pool).

in Id.

115 What are the "rights or privileges secured to citizens by the Constitution and laws of the United States?" If you mean to make it an offense to invade these rights, it is your duty as legislators to point out the precise offense intended. That could be made the basis, with a partial court, with an excited and partial jury, to convict a man . . . by raking up some possible right, throwing a dragnet over all the laws of the United States, over the Constitution of the United States . . . .

Id. at 3804 (remarks of Senator Bayard). 
These few remarks constitute the entire legislative history of section $241 ;{ }^{116}$ the remainder of the debate focused on other provisions of the Act. Moreover, the Enforcement Act as a whole sped through Congress, its final passage coming at 7:00 a.m. following an all-day and all-night session. ${ }^{117}$ Congress considered more than thirty amendments to the bill that morning, including section 241 , and the next session brought a heated debate over which amendments had been adopted and which had not.118

While the history of section 241 is not very illuminating, it demonstrates at the very least that Congress did not make a deliberate decision to provide criminal penalties for violations of any and every constitutional right that might come to be recognized. More specifically, the history of other sections of the Enforcement Act of 1870 and of subsequent federal vote fraud legislation shows that Congress has consistently refused to provide federal punishment for local vote fraud. Even though section 241 purports to encompass all rights secured by the Constitution, Congress has never intended to punish criminally local vote fraud.

In addition to section 241, the Enforcement Act of 1870 contained two sections punishing fraud and bribery in relation to registration $^{119}$ and voting ${ }^{120}$ in congressional elections. Congress limited these sections to congressional elections because it believed that it lacked the power to regulate voting practices in state and local elections for purposes other than preventing racial discrimination. ${ }^{21}$ Congress observed the same limitation in 1871, when it expanded and strengthened the enforcement provisions of the 1870 Act. ${ }^{122}$ In 1894, when control of Congress changed hands, all of the 1870-71 elections legislation except section 241 was repealed. ${ }^{23}$ Subsequent

116 As Justice Frankfurter remarked in United States v. Williams, 341 U.S. 70, 74-75 (1951) (footnote omitted), "While the discussion of the bill as a whole fills about 100 pages of the Congressional Globe, only two or three related to $\S$ [241], and these are in good part a record of complaint that the section was inadequately considered or understood."

177 GLOBE, supra note 112, at 3690.

"1x Id. at 3700-03.

119 Act of May 31, 1870, ch. 114, $\$ 20,16$ Stat. 145.

120 Act of May 31, 1870, ch. 114, § 19, 16 Stat. 144.

121 GLOBE, supra note 112, at 3571 (remarks of Senator Morton); see Ex parte Siebold, 100 U.S. 371, 393 (1879); United States v. Reese, 92 U.S. 214 (1875), discussed at note 25 supra.

122 Act of Feb. 28, 1871, ch. 14, 16 Stat. 433; see Cong. Globe, 41st Cong., 3d Sess. 1276 (1871) (remarks of Rep. Jones and Rep. Lawrence). For a thorough description of these provisions and their operation, see Burke, Federal Regulation of Congressional Elections in Northern Cities, 1871-94, 14 AM. J. LEGAL HIST. 17 (1970) [hereinafter cited as Burke].

124 Act of Feb. 8, 1894, ch. 25, 28 Stat. 36. The purpose of the repeal was to give the states control once again over their own elections. H.R. REP. No. 18, 53d Cong., 1st Sess. 7 (1893). 
Congresses reenacted many criminal provisions relating to elections, but none extended to state or local elections. ${ }^{24}$

In the 1960s Congress asserted some control over local elections in order to protect the voting rights of minority groups, ${ }^{125}$ but persistently refused to attempt to extend federal control to local vote fraud as well. In 1964 then-Congressman John Lindsay successfully led the opposition to an amendment to the Civil Rights Act of $1964^{128}$ that would have covered local vote fraud..$^{127}$ The next year, various bills were proposed that would have made vote fraud in any election a federal offense. ${ }^{128}$ These proposals were heavily criticized on policy and constitutional grounds and the final legislation was limited to elections for federal officials. ${ }^{29}$

Drawing inferences from legislative history is always hazardous, and no less so here. ${ }^{130}$ Congress, for example, did not believe

See also 26 Cong. Rec. 1990 (remarks of Senator Bate); id. at 1997 (remarks of Senator Stewart) (1894).

Section 241 was left in force, perhaps because it had been applied to protect rights other than voting rights. Logan v. United States, 144 U.S. 263 (1892) (protection of federal prisoners); United States v. Waddell, 112 U.S. 76 (1884) (rights under Homestead Act of 1862).

${ }^{124}$ In 1918, for example, an act punishing bribery was amended on the Senate floor to make clear that state and local elections were not covered. 18 U.S.C. $\$ 597$ (1970); see 56 Cong. Rec. 8762-63 (1918). See also Federal Corrupt Practices Act of 1925, ch. 368, 43 Stat. 1070, as amended, 2 U.S.C. $\S \S 431-54$ (Supp. III, 1973), governing disclosure of campaign spending.(see 84 ConG. REc. 9597 (1939)); section 104(a)(5) of the Civil Rights Act of 1964, 42 U.S.C. $\& 1975$ (c) (1970), extending the jurisdiction of the Commission on Civil Rights to the investigation of vote fraud in federal elections (see H.R. REP. No. 995, 87th Cong., 1st Sess. 6 (1961); 110 Cong. Rec. 2297 (1964)).

${ }^{125}$ See Civil Rights Act of 1960 and Voting Rights Acts of 1965 and 1970, 42 U.S.C. $\S \S$ $1971-74 \mathrm{e}(1970)$.

${ }^{126} 42$ U.S.C. $\$ \S 2000$ a to a-6 (1970).

127110 CONG. REC. 1706-09 (1964) (remarks of Rep. Lindsay). Representative Lindsay opposed the amendment on policy grounds, arguing that Congress had the power to reach local vote fraud but should not exercise it because the offense traditionally had been left to state control. See id. at 1709. Representative Celler took the same position. See id. at 1707.

${ }^{12 x}$ See, e.g., H.R. Rep. No. 439, 89th Cong., 1st Sess. 5, 30-31, 50 (1965). See also 111 CoNG. REc. 8423-24 (1965) (remarks of Senator Williams).

128 Cong. Rec. 8431-32 (1965) (remarks of Senator Hart). The final version, codified at 42 U.S.C. $\$ 1973 \mathrm{i}(\mathrm{c})(1970)$, is discussed at note 5 supra. Section $1973 \mathrm{i}(\mathrm{e})$, added in 1975 , prohibits voting more than once but is similarly limited to federal elections.

Section 1973i(a) states that "No person acting under color of law shall fail or refuse to permit any person to vote who is entitled to vote under any provision of this subchapter or is otherwise qualified to vote, or willfully fail or refuse to tabulate, count, and report such person's vote," and section 1973j(a) makes violation of the section a felony. Although this section might be read to reach vote fraud in state and local elections without racial discrimination, the courts have limited it to reach racially-motivated election irregularities. See Powell v. Power, 436 F.2d 84, 86-87 n.6 (2d Cir. 1970); Newell v. Troy, 343 F. Supp. 1253, 1255-56 (E.D.N.Y. 1972); cf. United States v. Executive Comm. of the Democratic Party, 254 F. Supp. 537, 540-41 (S.D. Ala. 1966).

${ }^{130}$ See generally Frankfurter, Some Reflections on the Reading of Statutes, 47 CoLum. 
that it possessed the power to legislate with respect to local vote fraud when it enacted the 1870-71 election legislation. ${ }^{131}$ Thus, it is impossible to divine what Congress would have done had it felt that it possessed the power to regulate local vote fraud. It can, of course, be argued that Congress desired to employ its power to penalize constitutional violations to the fullest and therefore chose to make every constitutional right-including the right to be protected from local vote fraud-punishable automatically upon being recognized. ${ }^{132}$ But in making this argument, several facts should be borne in mind: (1) Congress did not make a deliberate decision to penalize the violation of every constitutional right that later came to be recognized; (2) Congress has consistently refused to attempt to regulate local vote fraud, although almost always expressing constitutional doubts as a reason; ${ }^{133}$ (3) the Supreme Court has had to construe the language of section 241 narrowly to avoid having to declare the statute unconstitutionally indefinite; ${ }^{134}$ and (4) until recently, the Supreme Court was unsure that section 241 was meant to cover the fourteenth amendment at all. ${ }^{135}$ In these circumstances, the danger that expanding section 241 to include local vote fraud would extend the criminal law beyond congressional intent is hardly insubstantial. The next section examines the extent to which this legislative history can be used to restrict section 241's scope.

L. Rev. 527, 543-44 (1947); Nunez, The Nature of Legislative Intent and the Use of Legislative Documents as Extrinsic Aids to Statutory Interpretation: A Reexamination, 9 CAL. WEST. L. REv. 128 (1972); Radin, Statutory Interpretation, 43 HARv. L. Rev. 863, 869-73 (1930).

131 Text and notes at notes 120-22 supra. The States' Rights Democrats undoubtedly would have opposed the measure even if the congressional power had been apparent. However, the Radical Republican majority that passed the legislation seemed perfectly willing to attempt to exert federal control over state elections. GLOBE, supra note 112, at 3673. See generally FlACK, The Adoption OF THE FouRTEENTH AMENDMENT (1908); Burke, supra note 122.

${ }^{132}$ For example, a belief in 1870 that the legislation did not apply to those who (at that time, legally) prevented a woman from voting could not have barred its use in such a case today. But compare Commonwealth v. Welosky, 276 Mass. 398, 177 N.E. 656 (1931), and People ex rel. Fyfe v. Barnett, 319 Ill. 403, 150 N.E. 290 (1925), with Commonwealth v. Maxwell, $271 \mathrm{~Pa} .378,114$ A. 825 (1921) (effect of nineteenth amendment on statutes defining jury rolls in terms of qualified voters).

${ }^{133}$ See, e.g., 5 Cong. REc. 1803-04 (1893); 111 Cong. Rec. $8431-32$ (1965) (remarks of Senator Hart). The sponsor of the 1965 vote fraud amendments drafted a proposal covering all elections, and vigorously defended both its constitutionality and its necessity. Three days later, though, when an amendment limiting the provision to federal elections was offered to "make it constitutional," the sponsor accepted it as making his measure even "stronger." 111 CoNG. REc. 8423-25, 8432 (remarks of Senator Williams); id. at 8975 (remarks of Senator Ervin and Senator Williams) (1965). No explanation for this change of position appears in the recorded debates. See also note 91 supra.

131 Screws v. United States, 325 U.S. 91 (1945).

${ }^{135}$ See note 68 supra. 


\section{B. The Role of Legislative History in Construing Section 241}

The problem with using section 241 to apply criminal penalties to all constitutional violations regardless of congressional intent is that the decision to expand the criminal laws should be legislative and not judicial. ${ }^{136}$ The decision depends on such factors as (1) the suitability of criminal penalties to punish violations; ${ }^{137}$ and (2) the suitability of federal criminal penalties, taking into account the cost of federal prosecution and the competing demands on prosecutorial and enforcement resources, the possibility of friction between federal and local enforcement officials, and the like. ${ }^{138}$ When Congress passes legislation it can decide whether these factors justify federal criminal enforcement. But the Supreme Court cannot limit its decisions interpreting the Constitution by these considerations. Automatically applying federal criminal penalties to violations of every right announced by the Court would mean that a policy decision based on these factors need never be made.

Recognition of these problems has shaped the Court's construction of other criminal statutes. The principle of strict construction of penal statutes is itself partly designed to ensure that the legislature has made the decision to punish the conduct involved. ${ }^{139}$ The Burger Court has been particularly careful to construe criminal statutes narrowly to avoid overlapping federal and state enforcement efforts, noting that it is for Congress and not the courts to choose to bypass state enforcement and to expend limited federal enforcement resources in a particular area. ${ }^{140}$ The purpose of requiring Congress to express its decision clearly when it makes such a choice, the Court has stated, is to ensure "that the legislature has in fact faced,

${ }^{138}$ United States v. Wiltberger, 18 U.S. (5 Wheat.) 76, 93 (1820); cf. United States v. Gradwell, 243 U.S. 476, 485 (1917); United States v. Hudson, 11 U.S. (7 Cranch) 32 (1812) (no common law federal crimes).

137 For example, state legislators who pass unconstitutional laws may be guilty of violating constitutional rights, but this hardly means that criminal prosecutions would be the appropriate remedy. $C f$. Tenney v. Brandhove, 341 U.S. 367 (1951) (civil penalties under 42 U.S.C. $\$ 1983$ (1970) do not apply to state legislators).

138 Cf. United States v. Bass, 404 U.S. 336, 350 (1971). Another factor, and one which motivated the 1870 elections legislation, is whether locally elected officials will be faced with a conflict of interest in prosecuting local vote fraud. GLOBE, supra note 112, at 3809 . See generally Note, Double Prosecution by State and Federal Governments: Another Exercise in Federalism, 80 HaRv. L. REv. 1538, 1551-54 (1967).

139 United States v. Bass, 404 U.S. 336, 338 (1971); United States v. Wiltherger, 18 U.S. (5 Wheat.) 76, 93 (1820). The other major purpose is to insure that no one is punished without fair warning that his acts were criminal. See note 58 supra.

140 United States v. Bass, 404 U.S. 336, 348-50 (1971). But cf. United States v. Feola, 420 U.S. 636 (1975). See also United States v. Enmons, 410 U.S. 396 (1973); Rewis v. United States, 401 U.S. 808 (1971). 
and intended to bring into issue, the critical matters involved "141

These considerations argue strongly for allowing legislative histories to be used to limit the scope of section 241: in this case, for refusing to apply it to local vote fraud. However, such a cure seems likely to create more problems than it would solve. The effect would be to read every congressional debate since 1870 as potentially changing the scope of section 241 , even though no legislation has been passed. But congressional debates are always susceptible of many interpretations, and courts have been especially reluctant to draw inferences from refusals to pass legislation. ${ }^{142}$ In the case of section 241 the inferences would be drawn not merely from the history of section 241 itself but from the history. generated each time the subject at issue had been congressionally considered. ${ }^{143}$ Moreover, as an examination of the uncertain way in which the Court has used legislative histories to determine the scope of section 241 will show, reliance on such materials does not lend itself to principled adjudication.

Where the question has been whether section 241 can be used to punish violation of a right created by statute, the lower courts have been willing to construe section 241 as not including that right if the legislative history of the statute creating the right suggests that criminal enforcement was not intended. ${ }^{144}$ On the other hand, where the question has been whether section 241 can be used to punish violation of a judicially recognized constitutional right, the Supreme Court has vacillated on whether the history of either section 241 or subsequent legislation should be considered. The trend, though, seems to be in the direction of not relying on legislative history in this context.

14 United States v. Bass, 404 U.S. 336, 349 (1971).

is2 Cf. Girouard v. United States, 328 U.S. 61 (1946); H. HART \& A. SACKs, The Legal Process: Basic Problems in the Making and Application of Law 1394-1401 (tent. ed. 1958).

133 Vote fraud is a case in point: legislation which reflected congressional intentions on the subject was considered in 1870-71, 1894, 1918, 1925, 1960, 1964, 1965 and 1975. See text and notes at notes 110-29 supra. An inference of congressional intent which was sound in 1876 may be completely unfounded in 1976; any theory of interpreting section 241 to accord with congressional intentions faces the difficulty of changing the scope of section 241 as congressional moods change.

i" United States v. Johnson, 390 U.S. 563 (1968) (rights under the Civil Rights Act of 1964); United States v. De Laurentis, 491 F.2d 208 (2d Cir. 1974) (rights under section 7 of the National Labor Relations Act); see United States v. Bailes, 120 F. Supp. 614 (S.D.W. Va. 1954); United States v. Berke Cake Co., 50 F. Supp. 311 (E.D.N.Y.), appeal dismissed, 320 U.S. 807 (1943). In these cases the court needed to look only at the history of one statute, and one which was enacted into law, so the difficulties of relying on legislative history are not as great. 
In 1915, after Congress had repealed most of the 1870-71 legislation, ${ }^{145}$ the Supreme Court rejected in United States $v$. Mosley ${ }^{146}$ the argument that section 241 could not have been meant to punish vote fraud in congressional elections because, as certain repealed sections covered that behavior, Congress would have enacted redundant legislation. ${ }^{147}$ The Court instead read section 241 broadly, declaring that "we cannot allow the past so far to affect the present as to deprive citizens of the United States of the general protection which on its face section 19 (now section 241) most reasonably affords." 148 Shortly thereafter, however, the Court ignored this statement and in two cases relied on the argument rejected in Mosley, refusing to apply section 241 to vote fraud in primary elections ${ }^{149}$ and to bribery of voters. ${ }^{150}$ In 1941 , though, the Court again changed directions, reaffirmed Mosley, and applied section 241 to vote fraud in a congressional primary ${ }^{151}$ despite an argument based on the history of elections legislation. ${ }^{152}$

Since 1941 the Court's major concern with the legislative history of section 241 has involved the question of whether section 241 could be applied to violations of fourteenth amendment rights. This issue was raised though not resolved in United States $v$. Williams, with both sides relying heavily on the legislative history of section $241 .{ }^{153}$ This split was finally resolved in United States v. Price ${ }^{154}$ and United States $v$. Guest ${ }^{155}$ where the Court abjured the use of legislative history and announced that section 241 must be given a "sweep as broad as its language," to protect "all of the rights and privileges secured to citizens by all of the Constitution."

115 See text and note at note 123 supra.

us 238 U.S. 383 (1915).

it7 Id. at 391.92 (Lamar, J., dissenting); see text at note 149 supra. The Court also rejected the argument that, assuming Congress had intended to reach local vote fraud, the repeal of much of the Enforcement Act signalled a congressional intent to return control of the elections to the states.

148238 U.S. at 388.

"s United States v. Gradwell, 243 U.S. 476 (1917).

isa United States v. Bathgate, 246 U.S. 220 (1918).

${ }^{151}$ United States v. Classic, 313 U.S. 299 (1941).

${ }_{152}$ Id. at 323; id. at 331-39 (Douglas, J., dissenting). See also United States v. Saylor, 322 U.S. 385, 392 (1944) (Douglas, J., dissenting); Crolich v. United States, 196 F.2d 879 (5th Cir.), cert. denied, 344 U.S. 830 (1952).

${ }_{153}$ United States v. Williams, 341 U.S. 70 (opinion of Frankfurter, J.); id. at 87 (opinion of Douglas, J.) (1951); see note 68 supra.

158383 U.S. 745 (1966).

${ }^{135}$ Id. at 787 (1966).

${ }^{158} I d$. at $800-01$. Justice Douglas, reaching in dissent the issue avoided by the majority in Anderson v. United States, 417 U.S. 211 (1974), took the position that section 241 should 
effect held that the difficulty in developing a principled use of legislative histories in interpreting section 241 requires reading "any right" to mean any right.

If the Court were ever to limit these statements and sanction the use of legislative history in defining section 241's scope, local vote fraud would be an appropriate case. Congress has actually faced the issue of whether federal criminal penalties should be applied to local vote fraud, and in each case has decided against it: while the legislative history is not unambiguous, ${ }^{157}$ it will rarely be clearer than this. However, the trend in the cases seems to be against limiting section 241's scope by inferences of congressional intent, ${ }^{158}$ and the practical difficulties of any other approach ${ }^{159}$ probably justify this decision. The best solution may well be legislative rather than judicial: repeal of section 241 and its replacement with specific criminal penalties for violation of each right Congress wishes to enforce in this manner. ${ }^{160}$ While the question of whether to retain a statute which "violates virtually every canon of criminal law draftsmanship"161 is beyond the scope of this comment, ${ }^{162}$ the

not be construed to reach purely local vote fraud. Assuming that Congress today has the power to punish local vote fraud, he based his position partly on the ground that the "legislative history ... . indicates that Congress did not intend to reach local election frauds in passing $\S 241$, because it did not believe that it had the power." 417 U.S. at 244. He would have distinguished Guest and Price on the ground that there the application of section 241 did "not raise fundamental questions of federal-state relationships," 417 U.S. at 244, quoting United States v. Price, 383 U.S. at 806, while in Anderson it did.

Moreover, the Court has been as inconsistent in the weight it gives to this problem as in the weight it gives to legislative history. When the Court has held that section 241 does not cover particular conduct also punishable under state law, it has suggested that a contrary holding ought not to be reached in the absence of a more explicit congressional directive to bypass state enforcement. United States v. Bathgate, 246 U.S. 220, 225 (1918); United States v. Gradwell, 243 U.S. 476, 485 (1917); cf. United States v. Williams, 341 U.S. 70, $72-73$ (1951) (opinion of Frankfurter, J.). See also text and notes at notes 153-54 supra. When, on the other hand, the Court has read section 241 as reaching such conduct, it has expressed confidence that its decision will not significantly alter the relation between state and federal enforcement. E.g., United States v. Price, 383 U.S. 787, 806 (1966); Screws v. United States, 325 U.S. 91, 108-09 (1945).

157 See text and notes at notes 130-33 supra.

158 In United States v. Johnson, 390 U.S. 563 (1968), the Court turned to the legislative history of the Civil Rights Act of 1964 to see whether section 241 should apply criminal penalties to violations of that Act, and one court has read this as rejecting the "simplistic" approach of Price and Guest. United States v. De Laurentis, 491 F.2d 208, 212 (1974). However, both of these cases involved applying section 241 to statutory rights, see note 144 supra, and Price and Guest remain the latest decisions on section 241's coverage of constitutional rights.

${ }^{159}$ See text and notes at notes $142-43$ supra.

16018 U.S.C. $\$ 245$ (1970) does provide criminal penalties for violent interference with a number of specified rights. See note 85 supra.

is 2 Working PaPers, supra note 91, at 809.

162 The National Commission on Reform of Federal Criminal Laws recommended that 
difficulties courts must face in its application are strong arguments for its repeal.

\section{ConcLusion}

This comment has argued that the constitutional right to participate in state and local elections untainted by vote fraud has not yet been made sufficiently "specific" to permit punishing it under section 241 as construed in Screws v. United States. Although this objection could be met by a Supreme Court decision or a series of consistent circuit court decisions holding that local vote fraud violates constitutional rights-so long as criminal penalties are imposed only in future cases-there are still substantial objections to prosecuting local vote fraud under section 241. If the Court ever were to limit the sweeping statement in Price that section 241 protects "all of the rights and privileges secured to citizens by all of the Constitution," 163 the case of local vote fraud will be an appropriate one in which to do so.

Congress has, in a sense, spoken with two voices in regard to punishing local vote fraud. Congress has spoken in a general voice by declaring in section 241 that the violation of any secured constitutional right is a criminal act. But Congress has also spoken with a specific voice by considering extending federal criminal penalties to local vote fraud, and consistently refusing to do so. Given the fact that using legislative histories in this context does not lend itself to principled adjudication and that Congress itself is responsible for having spoken in a general voice to begin with, the ideal solution to problems like this one may be legislative-repealing section 241 -not judicial. Even though repeal of section 241 may be viewed as a political retreat from a strong civil rights position, the substitution of statutes punishing specified offenses would in fact facilitate the protection of civil rights by making prosecution a more certain enterprise.

Richard Craswell

section 241 be retained, although some commissioners disagreed. NAT'L CoMm'N ON REFoRM of Fed. Criminal Laws, Final Report 155-56 (1971). But see Feuerstein, Civil Rights Crimes and the Federal Power to Punish Private Individuals for Interference with Federally Secured Rights, 19 VAND. L. REv. 641, 675-82 (1966); Comment, Legislating Civil Rights: The Role of Sections 241 and 242 in the Revised Criminal Code, 63 Geo. L.J. 203, 217-18 (1974).

${ }^{163}$ United States v. Price, 383 U.S. 787, 800-01 (1966). 